\begin{tabular}{l} 
UAD \\
Universitas \\
Ahmad Dahlan \\
VOL. 2. No. 2, Juli 2021 \\
\hline
\end{tabular}

\title{
TINDAKAN SOSIAL TOKOH UTAMA DALAM NOVEL AKU MASENJA KARYA RUMASI PASARIBU: KAJIAN SOSIOLOGI SASTRA
}

\author{
Wijayanti Dwi Lestari \\ Email : wijayantidwilestari@gmail.com \\ Universitas Ahmad Dahlan, Yogyakarta \\ Dedi Pramono \\ Email : dedi.pramono@idlitera.uad.ac.id \\ Program Studi Sastra Indonesia, Fakultas Sastra, Budaya, dan Komunikasi \\ Universitas Ahmad Dahlan, Yogyakarta
}

Article history

Received 29 April 2021

Revised 24 July 2021

Accepted 27 July 2021

Keywords

social behavior

novel aku masenja

theory Max Weber
This research is motivated by the importance of one's actions in dealing with problem in everyday life, including the social life of the main character in the novel. This research aims to determine the forms of social behavior of the main character in the novel Aku Masenja by Rumasi Pasaribu. Social behavior theory refers to the theory social behavior from a male expert from Germany named Maximilian Weber or often called Max Weber. The research subject used is the novel Aku Masenja by Rumasi Pasaribu. The object this research is the social behavior of the main character based on Max Weber's theory. This research is a qualitative descriptive study. The data analysis technique uses the reading technique and the note taking technique. Then the results of the data analysis are presented in descriptive form. The results of this study indicate that the dominant form of social behavior that often appears in Aku Masenja is affective social behavior in the form of falling in love, anger, sadness, and suprise. While other actions such as behavior of instrumental rationality in the form of making decision, the desire to make parents happy, and the desire to protect students who are affected by the problem of values rationality behavior in the form moral values and religious values, tradisional behavior in the form of Pasemah community groups, the customs of a tribe in Bengkulu, the use of regional languages only a few forms appear.

This is an open access article under the CC-BY-SA license.
Article history

Received 29 April 2021

Revised 24 Juli 2021

Accepted 27 Juli 202

Keywords

tindakan sosial

novel aku masenja

teori max weber
Penelitian ini dilatarbelakangi oleh pentingnya tindakan seseorang dalam menghadapi permasalahan di kehidupan sehari-hari, termasuk kehidupan sosial tokoh utama di dalam novel. Penelitian ini bertujuan mengetahui bentuk-bentuk tindakan sosial tokoh utama dalam novel Aku Masenja karya Rumasi Pasaribu. Teori tindakan sosial mengacu pada teori tindakan sosial dari seorang pakar laki-laki asal Jerman bernama Maximilian Weber atau sering disebut Max Weber. Subjek penelitian yang digunakan adalah novel Aku Masenja karya Rumasi Pasaribu. Adapun objek penelitian ini adalah tindakan sosial tokoh utama berdasarkan teori Max Weber. Penelitian ini merupakan penelitian deskriptif kualitatif. Teknik analisis data menggunakan teknik baca dan teknik catat, selanjutnya hasil analisis data disajikan dalam bentuk deskriptif. Hasil penelitian ini menunjukkan hadirnya bentuk tindakan sosial yang dominan atau yang sering muncul dalam novel Aku Masenja adalah tindakan sosial afektif berupa tindakan jatuh cinta, marah, sedih, dan terkejut. Sedangkan tindakan lainnya seperti tindakan rasionalitas instrumental berupa pengambilan keputusan, keinginan membuat orangtua bahagia, dan keinginan melindungi anak murid yang terkena masalah, tindakan rasionalitas nilai berupa nilai moral dan nilai agama, tindakan tradisional berupa kelompok sosial masyarakat Pasemah, adat suatu suku di Bengkulu, penggunaan bahasa daerah hanya beberapa bentuk saja yang muncul. 


\section{PENDAHULUAN}

Permasalahan banyak ditemukan terutama dikehidupan yaitu antara manusia dengan jenis yang beragam yang mencakup hubungan manusia dengan Tuhan, manusia dengan manusia, serta manusia dengan batin seseorang. Kehidupan manusia digambarkan melalui tindakan sosial dalam menjalani kehidupan sehari-hari. Sebagai makhluk sosial, pastinya manusia dituntut untuk selalu berhubungan dengan orang lain. Oleh karena adanya hubungan inilah, tingkah laku seseorang sangat rentan dipengaruhi oleh perilaku orang lain. Karena tindakan sosial merupakan suatu tindakan individu yang diarahkan kepada orang lain dan memiliki arti baik bagi diri sendiri maupun orang lain.

Novel merupakan uraian cerita dari berbagai besar kehidupan manusia yang ditokohkan dalam cerita yang didalamnya terdapat berbagai jenis permasalahan yang harus dihadapi oleh tokoh tersebut. Dalam penelitian ini novel yang dipilih yaitu novel Aku Masenja karya Rumasi Pasaribu. Kelebihan dari novel ini terletak pada ceritanya, yakni tentang kehidupan seorang guru muda berprestasi yang dihadapkan beberapa permasalahan yang disebabkan oleh muridnya. Novel ini penuh inspirasi dimana seorang guru yang baru saja diangkat menjadi wali kelas harus melakukan tindakan yang baik dan benar demi untuk melindungi anak muridnya. Kelebihan pengarang novel Aku Masenja dirasa sudah cukup terkenal dan sudah cukup banyak karya-karyanya yang sudah diterbitkan. Hanya saja untuk data pribadi seorang Rumasi Pasaribu masih sulit atau sedikit ditemukan di media sosial kecuali pada blog pribadinya, facebook, dan Instagram. Tetapi, pengarang berani mengeluarkan karya baru yang dapat membangkitkan minat pembacanya. Pengarang mampu memberikan gambaran mengenai realita kehidupan melalui cerita yang disajikan dalam karya tersebut.

Pengarang novel Aku Masenja yakni Rumasi Pasaribu dalam menulis memiliki ide yang khas di dalam karya-karyanya. Rumasi Pasaribu menyelesaikan pendidikan terakhir di FKIP jurusan pendidikan Bahasa dan Sastra Indonesia Universitas Bengkulu. Saat ini tercatat sebagai guru di SMPN 16 Kota Bengkulu. Penulis pernah menjadi menjadi pemenang I Lomba Menulis Teks Bahan Ajar yang diadakan Kantor Bahasa Provinsi Bengkulu dan Juara III Lomba menulis cerpen KAMB (Komunitas Ayo Menulis Bengkulu). Tahun 2015, mendapat Anugerah Sastra Pemuda dari Lembaga Seni Kedai Proses Provinsi Bengkulu. Maka dari itu, pengarang mampu menciptakan karya-karya dengan bahasa yang sederhana, sehingga pembaca dapat lebih memahami makna yang disampaikan. Beberapa karyanya di antaranya Ocan dan Bimbim (2007), Aku Masenja (2007), Mengeja Tanda (2008), dan Boa Tarde, Senhor (2008).

Penelitian ini menggunakan kajian sosiologi sastra untuk menemukan bentuk tindakan apa saja yang ada di dalam novel Aku Masenja. Dalam hal ini yang menjadi sasarannya adalah kehidupan seorang tokoh utama Rona Masenja dalam berinteraksi dan diikuti dengan permasalahan-permasalahan yang terdapat di lingkungan sekolah dan masayarakat. Bisa dikaitkan dengan hal ini sosiologi sastra ini mengkaji aspek sosial seperti tindakan sosial di masyarakat. Seperti yang akan peneliti lakukan yaitu meneliti tindakan sosial dalam novel $A k u$ Masenja dan kemudian memaparkannya kepada pembaca. Tindakan sosial dalam sebuah novel keberadaannya sangat penting, karena sebagian besar novel menggunakan tema yang berkaitan dengan kehidupan manusia yang diperankan oleh tokoh lain, sehingga memunculkan adanya 


UADESIS
Universitas
Ahmad Dahlan

hubungan antara individu yang satu dengan yang individu yang lain. Hadirnya suatu tindakan sosial disebabkan oleh beberapa motif, salah satunya yaitu masalah-masalah yang berada di tengah masyarakat. Seperti halnya berada di tempat baru dengan orang-orang dan lingkungan yang baru juga, gambaran seperti itu akan memudahkan munculnya masalah seperti perbedaan pemikiran, sifat yang tidak menyenangkan, dan lain-lain yang sifatnya universal yang erat kaitannya dengan tindakan sosial.

\section{METODE}

Penelitian ini tergolong penelitian kualitatif yang memusatkan pada deskriptif. Subjek penelitian adalah novel Aku Masenja karya Rumasi Pasaribu dan objek penelitian adalah tindakan sosial tokoh utama dalam novel tersebut. Sumber data pada penelitian ini adalah Sumber data dalam penelitian ini adalah novel berjudul Aku Masenja karya Rumasi Pasaribu cetakan pertama, diterbitkan oleh Araska Publisher, Yogyakarta, Januari 2017 dan terdiri dari 248 halaman. Sumber data digunakan untuk menemukan ke-empat tipe tindakan sosial di antaranya tindakan sosial rasionalitas instrumental, tindakan rasionalitas nilai, tindakan afektif, dan tindakan tradisional yang dialami tokoh utama dalam novel Aku Masenja ditinjau dari teori sosiologi sastra. Sumber data lainnya yaitu buku-buku yang menjadi referensi serta kajian pustaka. Kajian ini menggunakan metode dan teknik pengumpulan data membaca dan mencatat.

Instrumen penelitian dalam kajian ini menggunakan alat berupa kartu data., yang digunakan untuk mencatat data-data kasus berupa kata, frase, kalimat, dialog, paragraf, maupun wacana yang berindikasi tindakan sosial yang melekat pada tokoh Rona Masenja dalam novel tersebut.

Teknik analisis data pada kajian ini menggunakan teknik analisis teks. Berdasarkan hal tersebut, peneliti menganalisis data dengan langkah-langkah sebagai berikut: mencari dan menentukan kutipan dalam novel Aku Masenja yang memiliki ciri-ciri tindakan sosial, mengelompokan data yang berkenaan dengan bentuk tindakan sosial dalam novel $A k u$ Masenja, menganalisis data dengan mengidentifikasi bagian-bagian yang berkenaan dengan bentuk tindakan sosial dalam novel Aku Masenja karya Rumasi Pasaribu, melakukan pembahasan tentang tindakan sosial, dan menyimpulkan data hasil penelitian tentang tindakan sosial.

\section{PEMBAHASAN}

\section{Tindakan Sosial Dalam Bentuk Rasionalitas Instrumental}

Untuk mengetahui hasil penelitian yang dilakukan terhadap novel Aku Masenja, ditemukan beberapa bentuk tindakan yang meliputi rasionalitas instrumental yang terdapat dalam novel, yang kemudian disajikan dalam tabel di bawah ini. 


MIMESIS
Universitas
Ahmad Dahlan

Tabel 1. Tindakan Sosial dalam Bentuk Rasionalitas Instrumental Pada Novel $A k u$

\begin{tabular}{|c|c|c|c|}
\hline \multicolumn{4}{|c|}{ Masenja } \\
\hline NO. & $\begin{array}{l}\text { TINDAKAN SOSIAL } \\
\text { RASIONALITAS } \\
\text { INSTRUMENTAL }\end{array}$ & DATA DARI NOVEL & HAL \\
\hline 1. & Pengambilan Keputusan & $\begin{array}{l}\text { 1. Memilih alat transportasi } \\
\text { 2. Memberi hukuman }\end{array}$ & $\begin{array}{r}15-170 \\
99-100\end{array}$ \\
\hline 2. & $\begin{array}{l}\text { Keinginan Membuat Orang Tua } \\
\text { Bahagia }\end{array}$ & 1. Berhasil meraih prestasi & 25,26 \\
\hline 3. & $\begin{array}{l}\text { Keinginan Melindungi Anak Murid } \\
\text { Yang Terkena Masalah }\end{array}$ & $\begin{array}{l}\text { 1. Mencuri karena masalah } \\
\text { ekonomi } \\
\text { 2. Remaja berdandan } \\
\text { berlebihan }\end{array}$ & $\begin{array}{c}33 \\
40-41\end{array}$ \\
\hline
\end{tabular}

Berdasarkan hasil penelitian pada tabel 1 menunjukan data mengenai tindakan sosial dalam bentuk rasionalitas instrumental yang ada dalam novel Aku Masenja berupa 1) pengambilan keputusan yaitu memilih alat tranportasi dan memberi hukuman, 2) keinginan membuat orang tua bahagia yaitu dengan berhasil meraih prestasi, dan 3) melindungi anak murid yang terkena masalah yaitu mencuri karena masalah ekonomi, dan remaja berdandan berlebihan.

\section{Tindakan Sosial Dalam Bentuk Rasionalitas Nilai}

Untuk mengetahui hasil penelitian yang dilakukan terhadap novel Aku Masenja, ditemukan beberapa tindakan sosial rasional nilai, yang kemudian disajikan dalam tabel di bawah ini.

Tabel 2. Tindakan Sosial dalam Bentuk Rasionalitas Nilai Pada Novel Aku Masenja

\begin{tabular}{|c|c|l|c|}
\hline NO. & $\begin{array}{c}\text { TINDAKAN SOSIAL } \\
\text { RASIONALITAS NILAI }\end{array}$ & HAL \\
\hline 1. & Nilai Moral & 1. Bertanggung jawab & 83 \\
\hline 2. & Nilai Agama & 1. Bertafakur & $59-112$ \\
& & 2. Berdoa kepada Allah SWT & 222 \\
\hline
\end{tabular}

Berdasarkan hasil penelitian pada tabel 2 menunjukan data mengenai tindakan sosial dalam bentuk rasionalitas nilai yang terdapat dalam novel Aku Masenja yang terdiri dari 1) nilai moral yang berupa bertanggung jawab, dan 2) nilai agama yang berupa tindakan yaitu bertafakur dan berdoa kepada Allah SWT. 


MIMESIS
Universitas
Ahmad Dahlan

\section{Tindakan Sosial Dalam Bentuk Afektif}

Untuk mengetahui hasil penelitian yang dilakukan terhadap novel Aku Masenja, ditemukan beberapa tindakan sosial rasional nilai, yang kemudian disajikan dalam tabel dibawah ini.

Tabel 3. Tindakan Sosial dalam Bentuk Afektif dalam Novel Aku Masenja

\begin{tabular}{|c|c|c|c|}
\hline NO. & $\begin{array}{l}\text { TINDAKAN SOSIAL } \\
\text { DALAM BENTUK } \\
\text { AFEKTIF }\end{array}$ & DATA DARI NOVEL & HAL \\
\hline 1. & Jatuh Cinta & $\begin{array}{l}\text { 1. Mencintai seseorang secara } \\
\text { sepihak }\end{array}$ & 233 \\
\hline 2. & Marah & $\begin{array}{l}\text { 1. Marah karena disindir teman } \\
\text { 2. Marah terhadap muridnya }\end{array}$ & $\begin{array}{c}125-126 \\
77 \\
\end{array}$ \\
\hline 3. & Sedih & $\begin{array}{l}\text { 1. Sedih karena dikhianati teman } \\
\text { 2. Sedih karena keadaan } \\
\text { 3. Menangis untuk seseorang }\end{array}$ & $\begin{array}{c}152 \\
86 \\
233-234 \\
\end{array}$ \\
\hline 4. & Terkejut & $\begin{array}{l}\text { 1. Seseorang dari masa lalu } \\
\text { kembali hadir }\end{array}$ & 244 \\
\hline
\end{tabular}

Berdasarkan hasil penelitian pada tabel 3 menunjukan data mengenai tindakan sosial dalam bentuk afektif yang terdapat dalam novel Aku Masenja berupa 1) jatuh cinta yaitu mencintai seseorang secara sepihak, 2) marah yaitu marah karena disindir teman, marah terhadap murid, 3) sedih yaitu sedih karena dikhianati, sedih karena keadaan, menangis untuk seseorang, dan 4) terkejut yaitu berupa seseorang dari masa lalu kembali hadir.

\section{Tindakan Sosial Dalam Bentuk Tradisional}

Untuk mengetahui hasil penelitian yang dilakukan terhadap novel Aku Masenja, ditemukan beberapa tindakan sosial tradisional, yang kemudian disajikan dalam tabel dibawah ini.

Tabel 4. Tindakan Sosial dalam Bentuk Tradisional dalam Novel Aku Masenja

\begin{tabular}{|c|l|c|c|}
\hline NO. & \multicolumn{1}{|c|}{$\begin{array}{c}\text { TINDAKAN SOSIAL } \\
\text { DALAM BENTUK } \\
\text { TRADISIONAL }\end{array}$} & HATA DARI NOVEL & HAL \\
\hline 1. & $\begin{array}{l}\text { Kelompok Sosial Masyarakat } \\
\text { Pasemah }\end{array}$ & $\begin{array}{l}\text { 1. Dianggap seperti keluarga } \\
\text { jauh }\end{array}$ & 49 \\
\hline 2. & $\begin{array}{l}\text { Adat Suatu Suku di } \\
\text { Bengkulu }\end{array}$ & $\begin{array}{l}\text { 1. Menjual anak laki-laki pada } \\
\text { suku Pasemah } \\
\text { Suku Pasemah mencari } \\
\text { pasangan dengan } \\
\text { 'Begadisan' } \\
\text { Suku Serawai mencari } \\
\text { pasangan dengan tari nandai }\end{array}$ & 63 \\
\hline 3. & Penggunaan Bahasa Daerah & $\begin{array}{l}\text { 1. Berbahasa Rejang } \\
\text { Berang }\end{array}$ & 79 \\
\hline
\end{tabular}




\begin{tabular}{|c|c|c|}
\hline $\begin{array}{l}\text { UnD } \\
\text { Universitas } \\
\text { Ahmad Dahlan }\end{array}$ & $\begin{array}{c}\text { MIMESIS } \\
\text { VoL. 2. No. 2, Juli } 2021\end{array}$ & \\
\hline
\end{tabular}

Berdasarkan hasil penelitian pada tabel 4 menunjukan data mengenai tindakan sosial dalam bentuk tradisional yang ada dalam novel Aku Masenja berupa kelompok sosial masyarakat Pasemah yaitu dianggap seperti keluarga jauh, adat suatu suku di Bengkulu yaitu menjual anak laki-laki pada suku Pasemah, suku Pasemah mencari pasangan dengan 'Begadisan', suku Serawai mencari pasangan dengan tari nandai, dan penggunaan bahasa daerah yang berbahasa Rejang.

\section{Tindakan Rasionalitas Instrumental}

\section{Pengambilan Keputusan "Memilih Alat Transportasi"}

Di bawah ini menunjukan contoh dalam pengambilan keputusan oleh tokoh utama:

"Mobil berguncang-guncang. Jalanan dipenuhi bebatuan sebesar kepalan tangan. Begini seterusnya hingga tiba di sekolah. Bila menggunakan sepeda motor, aku yakin takkan kuat untuk mengendalikannya, sebab guncangan amat berat dan bisa membuat ban sepeda motor bercericit lari. Akibatnya, tentu akan terjatuh. Dan perjalanan ini harus ditemnpuh selama hampir lima kilo" (Rumasi, 2017:15).

"Esok harinya, matahari telah lebih dari sepenggalah ketika aku berangkat sekolah. Seperti hari-hari biasa, aku menaiki mobil kompong setelah menitipkan sepeda motorku di salah satu rumah warga di simpang sebelum sekolah" (Rumasi,2017:170).

Kutipan di atas menjelaskan tentang Masenja yang memilih alat transportasi berupa mobil kompong untuk tiba ke sekolah tempat ia mengajar. Jalan yang dipenuhi bebatuan yang berukuran besar Masenja tidak yakin jika aman menggunakan motor. Maka dari itu, Masenja yang takut jika dirinya terluka memilih untuk menitipkan motornya ke salah satu rumah warga. Tindakan yang dilakukan tokoh utama di atas menandakan adanya tindakan sosial rasionalitas instrumental. Hal ini dapat dibuktikan sebelum melakukan tindakan seseorang sadar dengan apa yang dilakukan dan sadar akan tujuannya dari tindakannya. Seperti tindakan Masenja yang mengambil keputusan untuk menitipkan sepeda motornya dan memilih untuk menggunakan mobil kompong sebagai alat transportasi, tujuan kedepannya dari tindakan Masenja adalah agar dirinya tidak telat sampai ke sekolah tempat ia mengajar. Adapun tindakan instrumental yang ditunjukan tokoh utama dalam novel tersebut memiliki keterkaitan dengan lingkungan asli masyarakat. Tindakan mengambil keputusan memilih alat transportasi masih dapat kita jumpai hingga saat ini di lingkungan kita.

\section{Keinginan Membuat Orang Tua Bahagia "Berhasil Meraih Prestasi"}

Di bawah ini menunjukan contoh berupa keinginan membuat orang tua bahagia oleh tokoh utama:

"Kau tahu, aku selalu sekolah di sekolah-sekolah favorit, mendapat juara, dan menjadi mahasiswa lulusan terbaik - yang membuat bapak dan ibu menitikkan air mata begitu aku mendapat piagam penghargaan dan foto bersama rektor universitas ketika wisuda. Tak ada kebahagiaan bagi orang tua melihat keberhasilan anak-anaknya. Dapatkah kau bayangkan, di tengah isu KKN pada pengangkatan pegawai di republik ini, saat mustahil rasanya aku lulus murni, ternyata aku berhasil lulus tanpa korupsi, kolusi, juga nepotisme? Takdir telah berjalan seperti yang telah ditetapkan-Nya" (Rumasi, 2017:25). 
"Dan seperti yang telah abang dan kakakku katakan, hidupku teramat mudah dan mulus. Aku menjadi pegawai pemerintah, menjadi seorang guru—sesuai dengan latar belakang pendidikanku - di pedalaman satu-satunya kabupaten yang menerima guru bidang studi Matematika. Ketika aku sempat ragu-ragu untuk berangkat ke Kabupaten Bengkulu Utara - yang hanya ku dengar namanya saja sebelumnya — serta merta kedua kakakku protes. Alasan yang terlampau dibuat-buat kalau memasuki perkebunan yang menjadi sengketa, menjelajahi tanah merah dan beberapa belantara, melewati jalan berbatu sebesar kepalan tangan, adalah penyebab timbulnya keraguan dalam hatiku" (Rumasi,2017:26).

Kutipan di atas mendeskripsikan bagaimana orang tua Masenja bahagia melihat keberhasilan yang diterimanya atas prestasi yang diraih. Diawali dengan Masenja yang selalu bersekolah di sekolah favorit, mendapat juara, hingga menjadi mahasiswa lulusan terbaik. Masenja juga lulus murni tanpa korupsi, kolusi, dan nepotisme. Setelah itu, Masenja diangkat menjadi seorang guru matematika di Kabupaten Bengkulu Utara. Masenja sempat ragu untuk tetap menjadi guru di tempat yang selama ini ia dengar namanya saja karena beberapa alasan. Namun, hal ini tidak membuat Masenja goyah, Masenja tetap memilih untuk menjadi guru.

Tindakan yang dilakukan oleh tokoh utama di atas menandakan adanya tindakan instrumental. Hal ini dapat dibuktikan sebelum melakukan tindakan seseorang sadar dengan apa yang dilakukannya dan sadar akan tujuan dari tindakannya. Seperti yang dilakukan Masenja bahagia melihat orang tuanya bahagia dan bangga atas prestasi yang ia raih. Masenja tidak ingin mengecewakan orang tuanya memilih untuk tetap menjadi guru matematika mengingat latar belakang Masenja yang memang berasal dari pendidikan, walau berhadapan dengan banyak tantangan di depan seperti memasuki perkebunan yang menjadi sengketa, menjelajahi tanah merah dan beberapa belantara, melewati jalan berbatu sebesar kepalan tangan Masenja tetap yakin pada pendiriannya. Adapun tindakan instrumental yang ditunjukan tokoh utama dalam novel tersebut memiliki keterkaitan dengan lingkungan asli masyarakat. Tindakan keinginan membuat orang tua bahagia dengan berhasil meraih prestasi masih dapat kita jumpai di lingkungan kita saat ini.

\section{Keinginan Melindungi Anak Muridnya yang Terkena Masalah "Mencuri Karena Masalah Ekonomi"}

Di bawah ini menunjukan contoh tindakan keinginan melindungi anak muridnya yang dialami oleh tokoh utama:

"Saya rasa alasan saya tepat, Pak. Koruptor bebas berkeliaran atau dihukum dengan segala kemewahan, bahkan kadang-kadang tetap dielukan oleh para penjilat dan dianggap sedang difitnah. Sedang orang miskin yang mencuri untuk makan dihukum berat dan dipermalukan. Ah, izinkan saya mendidiknya, Pak. Sekali saja. Jika ia tetap mencuri, saya serahkan pada BK atau kepolisian" (Rumasi, 2017:33).

"Aku telah bersepakat dengan Bunga, untuk tak mengungkit lagi kenekatannya. Aku juga memintanya untuk segera mencuci baju yang ia curi dan menyerahkannya padaku. Nanti aku yang akan mengembalikannya pada Farid beserta uang lima belas ribu yang tentu saja kuambil dari kantongku" (Rumasi, 2017: 35-36). 


UADESIS
Universitas
Ahmad Dahlan

Kutipan di atas menjelaskan tentang Masenja yang memilih tidak mengambil tindakan yang berlebihan, menurutnya dengan mendidiknya akan membantu merubah pola pikirnya bahwa mencuri bukanlah pilihan yang tepat, bahkan Masenja membantu untuk meringankan beban Bunga dengan mengembalikan uang yang dicuri sebesar lima belas ribu rupiah. Tindakan yang dilakukan oleh tokoh utama di atas menandakan adanya tindakan instrumental. Hal ini dapat dibuktikan sebelum melakukan tindakan seseorang dengan apa yang dilakukannya dan sadar akan tujuan dari tindakannya. Seperti tindakan yang dilakukan Masenja yaitu berusaha untuk melindungi anak muridnya agar tidak dikeluarkan dengan cara mendidiknya, tujuan kedepannya dari tindakan Masenja adalah agar anak muridnya ini tidak mengulangi perbuatannya tersebut di lain waktu, serta agar anak tersebut dapat meneruskan pendidikannya. Adapun tindakan instrumental yang ditunjukan tokoh utama dalam novel $A k u$ Masenja tersebut memiliki keterkaitan dengan lingkungan asli masyarakat. Tindakan keinginan untuk melindungi anak muridnya yang terkena masalah seperti mencuri karena masalah ekonomi masih dapat kita jumpai di lingkungan sekolah.

\section{Tindakan Rasionalitas Nilai}

\section{Nilai Moral "Bertanggung Jawab"}

Di bawah ini menunjukan contoh nilai moral oleh tokoh utama:

"Kemarahanku berlipat-lipat. Aku berasumsi diam dan saling tatap adalah jawaban bahwa perbuatan itu tak dilakukan hanya sekali. Aku meradang"

"Kalau sudah siap menikah, besok kita ke penghulu saja. Itu lebih halal dan berkah, walau..." gumamku.

"Belum, Bu. Saya belum siap menikah. Saya, saya..."

"Saya apa?"

"Saya cuma penasaran".

"Aku semakin meradang" (Rumasi, 2017:83).

Kutipan di atas mendeskripsikan Masenja yang mengira tindakan yang dilakukan kedua muridnya tidak hanya dilakukan sekali, melainkan berkali-kali. Masenja selaku wali kelas sakit hati kemudiian mengajak kedua muridnya tersebut menikah. Tindakan yang dilakukan oleh tokoh utama di atas menandakan adanya tindakan rasionalitas nilai. Hal ini dapat dibuktikan dengan tindakan yang dilakukan oleh seseorang atas dasar nilai. Seperti yang dilakukan oleh Masenja yang bertanggung jawab sebagai wali kelas dengan mengambil keputusan menikahkan kedua muridnya yang melakukan tindakan mesum. Tindakan yang dilakukan oleh kedua muridnya merupakan tindakan yang salah. Nilai yang menjadi dasar Masenja melakukan tindakannya adalah nilai moral. Adapun tindakan rasionalitas nilai yang ditunjukan oleh tokoh utama dalam novel tersebut memiliki keterkaitan sosial karena tokoh utama beranggapan bahwa menikah merupakan tindakan yang termasuk dalam kriteria baik dan benar menurut ukuran dan penilaian masyarakat di sekitarnya.

\section{Nilai Agama "Berdoa kepada Allah SWT"}

Di bawah ini menunjukan contoh nilai agama oleh tokoh utama: 


UADESIS
Universitas
Ahmad Dahlan

"Dan tentang ini, Kakakku Gadis telah mengajarkan doa padaku, Ya Allah, jadikanlah aku manusia yang beruntung" (Rumasi, 2017: 222).

Dari kutipan di atas menjelaskan bahwa Masenja yang senantiasa berdoa kepada Allah swt untuk menjadikannya manusia yang beruntung. Beruntung dalam artian Masenja banyak belajar dari segala kejadian yang terjadi di pekerjaan kemudian menyadarkannya tentang bagaimana konsep semesta dan sekelilingnya bekerja. Tindakan yang dilakukan oleh tokoh utama di atas menandakan adanya tindakan rasionalitas nilai. Hal ini dapat dibuktikan dengan tindakan yang dilakukan oleh seseorang atas dasar nilai. Seperti tindakan yang dilakukan oleh Masenja untuk dirinya, Masenja selalu berdoa. Nilai yang menjadi dasar atas Masenja melakukan tindakannya adalah nilai agama. Adapun tindakan rasionalitas nilai yang ditunjukan oleh tokoh utama dalam novel Aku Masenja memiliki keterkaitan sosial dengan lingkungan masyarakat saat ini, karena setiap individu pastinya akan berdoa kepada Allah sebagai bentuk komunikasi dengan Sang Pencipta.

\section{Tindakan Afektif}

\section{Jatuh Cinta "Mencintai Seseorang Secara Sepihak"}

Di bawah ini menunjukan contoh tindakan jatuh cinta yang dialami oleh tokoh utama:

"Kami terus bercerita. Aku tak percaya bahwa kami telah menghabiskan sore itu bersama-sama, hampir dua jam lamanya. Dan aku tak merasa sedikit pun bosan mendengarnya bicara. Kau pasti mentertawakanku, meledekku hingga aku akan terlihat konyol di hadapanmu. Kau tentu merasa kegirangan melihat pipiku bersemu dengan wajah tertunduk malu. Tetapi denganmu, tak mampu kusembunyikan perasaanku. Kebersamaan hari ini sungguh menyenangkan. Kebersamaan yang redakan rindu yang diam-diam ku simpan sejak pertemuan dulu. Ah, apakah aku telah jatuh cinta pada lelaki itu? Apakah fitrah mencintai ini mulai menghampiriku? Aku tak mampu menjawabnya. Tapi sungguh, setelah ia pulang, aku merasa kehilangan" (Rumasi, 2017:220).

"Kalau ada yang mesti kutertawakan saat ini adalah diriku sendiri. Ku kira tembang cinta bergaung di dadanya, seperti gaungnya di dadaku. Tapi dugaanku keliru. Ternyata rasa itu hanya menari di hatiku. Tidak di hatinya. Dan parahnya, aku telah menafsirkan kehadirannya bagai embun temukan fajar. Menyongsong matahari bersama lalu sepakat menghilang untuk muncul berdua esok hari” (Rumasi, 2017: 233).

Dari kutipan di atas Masenja mendeskripsikan dirinya jatuh cinta kepada karyawan yang bekerja di perkebunan sawit karena memiliki tutur kata yang diucapkan dirasa halus dan sopan yang membuat dirinya berwibawa dan memiliki mata yang teduh. Hal tersebut membuat Masenja berharap bahwa cintanya akan terbalas, namun pria terebut rupanya tidak merasakan hal yang sama. Pria tersebut hanya menganggap Masenja sebagai teman. Tindakan yang dilakukan oleh tokoh utama menandakan adanya tindakan afektif. Hal ini dapat di buktikan dengan tindakan yang terjadi secara spontan oleh individu dan berdasarkan perasaannya. Seperti yang dilakukan oleh Masenja yang jatuh cinta dengan seseorang yang bernama Habil. Karena kepribadian Habil yang baik maka secara tidak sadar dengan mudahnya membuat 


UAD
Universitas
Ahmad Dahlan

Masenja jatuh cinta. Tapi saat Masenja yakin dengan perasaannya, hal buruk justru menimpanya Masenja hanya mencintai Habil secara sepihak. Adapun tindakan afektif yang ditunjukan oleh tokoh utama dalam novel Aku Masenja memiliki keterkaitan sosial dengan lingkungan masyarakat. Mencintai seseorang secara sepihak adalah hal yang lumrah.

\section{Marah "Marah Terhadap Murid"}

Di bawah ini menunjukan contoh tindakan marah yang di alami oleh tokoh utama:

"Astaghfirullah, berungkali aku istighfar. Sinting! Dunia sudah gila.".

"Aku tak mampu menahan amarahku pada dua sosok yang duduk di hadapanku. Dadaku berderap. Ingin kutampar kedua pipi mereka, namun teriakan HAM yang selalu bergaung hingga sudut semesta mengurungkanku. Aku menelan ludah. Pahit”.

"Ini sungguh perbuatan seorang manusia yang rendahan. Bahkan semestinya mereka dirajam! Dan kepalaku teramat pusing, sebab gemetar membuatku lemah dan lelah".

"Memalukan. Kalau tak tahan lagi, ah...! Tak usah sekolah lagi! Genit! Kurang ajar!" (Rumasi, 2017:76-77).

Berdasarkan kutipan di atas, Masenja mendeksripsikan dirinya marah kepada anak muridnya karena telah melakukan tindakan yang tidak pantas dilakukan oleh anak dibawah umur di sekolah, akan tetapi rasa marah yang dirasakan Masenja harus ditahan karena mengingat melakukan tindakan fisik seperti memukul seseorang akan menambah masalah karena adanya HAM yang berlaku. Tindakan yang dilakukan oleh tokoh utama menandakan adanya tindakan afektif. Hal ini dapat di buktikan dengan tindakan yang terjadi secara spontan oleh individu dan berdasarkan perasaannya. Seperti yang dilakukan oleh Masenja yang terbawa amarah mencoba untuk bertindak kasar bahkan menginginkan mereka untuk dirajam, menurutnya mesum di sekolah merupakan perbuatan terlarang dan sangat di benci Tuhan. Adapun tindakan afektif yang ditunjukan oleh tokoh utama dalam novel Aku Masenja memiliki keterkaitan sosial dengan lingkungan masyarakat. Marah terhadap murid pernah dirasakan beberapa guru.

\section{Sedih "Sedih karena dikhianati Teman"}

Di bawah ini menunjukan contoh tindakan sedih yang dialami oleh tokoh utama:

"Aku teringat malu dan sedih serta khawatir ketika orang-orang yang kukira berada dipihakku ternyata menjerumuskanku, menjadi musuh yang terang-terangan mengulitiku ketika aku mulai percaya dan bersandar penuh" (Rumasi, 2017:152).

Kutipan di atas menjelaskan Masenja yang sedih mengingat kejadian saat teman yang selama ini di percaya dan berada dipihaknya justru bermuka dua dan mengkhianati dirinya. Tindakan yang dilakukan oleh tokoh utama menandakan adanya tindakan afektif. Hal ini dapat di buktikan dengan tindakan yang terjadi secara spontan oleh individu dan berdasarkan perasaannya. Seperti yang dilakukan Masenja yang sedih karena ekspetasi Masenja pada teman-temannya yang dipikirannya selalu berada dipihaknya namun ternyata salah, justru pada kenyataannya mereka mengkhianati dirinya. Adapun tindakan afektif yang ditunjukan oleh tokoh utama dalam novel tersebut memiliki keterkaitan sosial dengan lingkungan masyarakat. 
Sedih karena dikhianati teman merupakan hal yang bisa dirasakan oleh semua orang mengingat bahwasanya seorang teman terkadang tidak selamanya baik.

\section{Terkejut "Seseorang Dari Masa Lalu Kembali Hadir"}

D ibawah ini menunjukan contoh tindakan terkejut yang dialami oleh tokoh utama:

"Aku hampir melompat dari kursiku begitu mendengar kata-kata yang mengalir dengan tenang begitu saja di telepon genggamku. Dadaku berderap. Keringat mengucur dari balik jilbabku. Tanganku basah hingga beerapa jenak aku belum juga menjawab pertanyaannya".

"Bagaimana bisa empat tahun sejak aku pindah ia tak menghubungiku dan hari ini sekonyong-sekonyong datang setelahnya menelponku?” (Rumasi, 2017: 244).

Kutipan di atas menjelaskan Masenja terkejut ketika mengangkat telepon yang ternyata dari seseorang dimasa lalunya yaitu Habil Sanjaya. Setelah empat tahun tidak ada kabar, tidak menelpon, atau sms dan secara tiba-tiba saja menanyakan kabar. Tindakan yang dilakukan oleh tokoh utama menandakan adanya tindakan afektif. Hal ini dapat di buktikan dengan tindakan yang terjadi secara spontan oleh individu dan berdasarkan perasaannya. Seperti yang dilakukan Masenja yang hampir melompat dari kursinya karena terkejut mendapat telepon dari Habil. Dalam hal ini Habil merupakan masa lalu yang kembali hadir kepada Rona Masenja rupanya ingin kembali menjalin komunikasi dengannya karena dahulu sempat terputus. Adapun tindakan afektif yang ditunjukan oleh tokoh utama dalam novel Aku Masenja memiliki keterkaitan sosial dengan lingkungan masyarakat. Terkejut karena seseorang dari masa lalu kembali hadir merupakan tindakan yang spontan terjadi yang bisa saja dialami oleh salah satu pihak umumnya laki-laki mengingat seseorang bisa kapanpun berubah pikiran, terutama jika dirinya belum bisa melupakan orang tersebut.

\section{Tindakan Tradisional}

\section{Kelompok Sosial Masyarakat Pasemah "Dianggap Seperti Keluarga Jauh"}

Di bawah ini menunjukan contoh kelompok sosial masyarakat Pasemah oleh tokoh utama:

"Aku memandangnya. Setahuku, masyarakat Pasemah bila bertemu dengan sesamanya di perantauan akan merasa seperti bertemu 'keluarga jauh'. Dan tanpa disadari, mereka langsung merasa dekat. Ah, kurasa keberuntungan berada di pihakku. Kukira dengan mengatakan bahwa ayahku dari Pasemah, Bapak Farid akan bisa kuajak bekerjasama, menerima pemikiran -pemikiranku” (Rumasi, 2017: 49).

Kutipan di atas menjelaskan tentang Masenja yang bertemu dengan orang tua murid yang juga berasal dari Pasemah. Masenja berharap dengan adanya kesamaan tempat tinggal dapat mempermudah dalam berkomunikasi. Tindakan yang dilakukan oleh tokoh utama menandakan adanya tindakan tradisional. Hal ini dapat dibuktikan dengan latar belakang kehidupan yang menonjol dalam kebiasaan pola hidup yang diterapkan oleh Masenja. Seperti 


UADESIS
Universitas
Ahmad Dahlan

pada tindakan Masenja yang menerapkan pengetahuannya mengenai latar belakang masyarakat Pasemah jika bertemu sesamanya di perantauan akan dianggap seperti keluarga jauh yang hingga saat ini masih dilakukan sebagai ciri khusus untuk membedakan dengan masyarakat umum. Tindakan dengan dianggap seperti keluarga jauh ini sudah menjadi kebiasaan masyarakat Pasemah dalam hal ini bertujuan supaya tidak canggung dan jauh lebih dekat satu sama lain. Adapun tindakan tradisional yang dilakukan Masenja ini memiliki keterkaitan sosial dengan lingkungan asli masyarakat.

\section{Adat Istiadat Suatu Suku "Suku Pasemah Mencari Pasangan Adat dengan Begadisan"}

Di bawah ini menunjukan contoh adat istiadat suatu suku oleh tokoh utama:

"Bahkan Ibu yang lebih dekat denganku dan lebih banyak bercerita tentang 'perempuan' pernah menceritakan bahwa adat suku Pasemah membiasakan untuk mencari pasangan dengan melewati belakang rumah atau biasa disebut begadisan. Lakilaki mengobrol dibawah rumah panggung, sementara sang gadis duduk di dapurnya, di dalam rumah panggung" (Rumasi,2017:79).

Kutipan di atas mendeskripsikan Masenja sedang menceritakan pengetahuan sang ibu yang bercerita kepadanya mengenai seseorang sangat menjunjung tinggi adat istiadatnya terutama suku Pasemah bahwasanya seorang perempuan dalam mencari pasangan harus mengikuti adat begadisan pada malam hari, tepatnya pada malam Minggu atau malam libur sekolah. Melewati belakang rumah atau begadisan merupakan sebuah kebiasaan masyarakat apabila seorang perempuannya sedang mencari pasangan. Tindakan yang dilakukan Masenja ini termasuk menggambarkan tindakan sosial tradisional karena laki-laki mengobrol dibawah rumah panggung, sementara yang gadis duduk di dapurnya, di dalam rumah panggung menjadikan kebiasaan ketika seorang perempuan menjemput jodohnya. Hal ini dilakukan secara terus-menerus bahkan sejak dulu sehingga dijadikannya kebiasaan. Adapun tindakan tradisional yang dilakukan Masenja ini memiliki keterkaitan sosial dengan lingkungan asli masyarakat.

\section{Penggunaan Bahasa Daerah "Berbahasa Rejang"}

Di bawah ini menunjukan contoh penggunaan bahasa daerah oleh tokoh utama:

"Si bi balek moi sadei nenekne. Ia tak mau sekolah lagi. Sudoyo ku murus suet kaliak ne mako si tep skulah (Ia sudah pergi ke dusun neneknya. Akan kuurus surat pindahnya supaya ia tetap sekolah)".

"Bahasa dan logat daerah yang kental. Perempuan ini mestilah perempuan bersuku Rejang. Sedari tadi sejak bicara denganku, ia telah menggunakan penggalan kalimat berbahasa Rejang, salah satu bahasa daerah di tanah Bangkahulu. Aku tak pandai bicara bahasa ini, tapi sedikit mengerti sebab banyak juga teman-temanku yang menggunakan bahasa Rejang. Beberapa paman dan bibi dari pihak ayah dan ibuku bahkan menikahi lelaki atau perempuan bersuku Rejang. Sebagian besar penduduk yang masuk ke dalam kategori suku tertua di Sumatera ini mendiami wilayah Rejang Lebong atau daerah Lebong" (Rumasi, 2017: 188). 


UADESIS
Universitas
Ahmad Dahlan

Kutipan di atas menjelaskan tentang Masenja yang sedang berbicara dengan orang tua murid yaitu ibu dari Alfi Rozas. Rupanya ibu Alfi ini menggunakan bahasa daerah yaitu bahasa rejang. Masenja yang tidak mengerti akan bahasanya mencoba menanggapi dengan semampunya mengingat sebagian besar teman-temannya berasal dari suku Rejang bahkan paman dan bibi dari pihak ayah dan ibunya juga menikahi lelaki atau perempuan yang berasal dari suku Rejang. Tindakan yang dilakukan Masenja ini termasuk menggambarkan tindakan sosial tradisional karena menggunakan bahasa Rejang yang sudah menjadi kebiasaan temantemannya sehingga Masenja dapat memahami sedikit bahasa Rejang. Adapun tindakan tradisional yang dilakukan Masenja ini memiliki keterkaitan sosial dengan lingkungan asli masyarakat suku Rejang.

Dari ke-empat tipe tindakan sosial yang terdapat dalam novel Aku Masenja karya Rumasi Pasaribu ini yang paling dominan atau yang paling sering muncul ialah tindakan sosial afektif. Hal ini karena tindakan yang dilakukan tokoh utama Masenja banyak didominasi oleh perasaan seperti jatuh cinta, sedih, marah, bahkan terkejut. Dari segala permasalahan yang dialami tokoh utama, Masenja banyak mengekspresikannya dengan perasaan, karena permasalahan-permasalahan tersebut datangnya secara spontan atau mengalir begitu saja sehingga tidak ada perencanaan terlebih dahulu. Sedangkan tipe tindakan rasionalitas instrumental, tindakan rasionalitas nilai, dan tindakan tradisional hanya beberapa bentuk tindakan sosial saja yang muncul.

\section{KESIMPULAN}

Berdasarkan hasil penelitian yang telah dilakukan dapat disimpulkan bahwa tindakan sosial tokoh utama dalam novel Aku Masenja karya Rumasi Pasaribu dengan kajian sosiologi sastra Max Weber terdapat empat tipe tindakan sosial yaitu, tindakan rasionalitas instrumental, tindakan rasionalitas nilai, tindakan afektif, dan tindakan tradisional. Dari ke-empat tipe tindakan sosial tersebut yang paling sering muncul atau dominan ialah tindakan afektif. Sedangkan tipe tindakan rasionalitas instrumental, tindakan rasionalitas nilai, dan tindakan tradisional hanya beberapa bentuk tindakan sosial saja yang muncul. Beberapa tipe tindakan sosial yang dapat ditemukan dalam novel Aku Masenja karya Rumasi Pasaribu ini di antaranya:

1. Bentuk tindakan rasionalitas instrumental yang ditemukan dalam novel Aku Masenja, di antaranya pengambilan keputusan, keinginan membuat orang tua bahagia dan keinginan melindungi anak murid yang terkena masalah.

2. Bentuk tindakan rasional nilai yang ditemukan dalam novel Aku Masenja, di antaranya nilai moral dan nilai agama.

3. Bentuk tindakan afektif yang ditemukan dalam novel Aku Masenja, di antaranya tindakan jatuh cinta, marah, sedih dan terkejut.

4. Bentuk tindakan tradisional yang ditemukan dalam novel Aku Masenja, di antaranya kelompok sosial masyarakat Pasemah, adat istiadat suatu suku, dan penggunaan bahasa daerah. 


UAD
Universitas
Ahmad Dahlan

\section{DAFTAR PUSTAKA}

Alis, M., \& Norkholis. (2016). Analisis tindakan sosial Max Weber dalam tradisi pembacaan kitab Muktashar Al-Bukhari. Jurnal Living Hadis Vol 1 Nomor 2. Diambil dari http://ejournal.uin-suka.ac.id/ushuluddin/Living/article/view/1121

Anwar, Y \& Adang. (2013). Sosiologi untuk universitas. Bandung: Refika Aditama.

Cintya, N.I. (2019). Konflik psikologi dalam novel Aku Masenja karya Rumasi P. dan relevansinya dengan pembelajaran sastra di perguruan tinggi. Prosiding Seminar Nasional. Diambil dari http://pgsd.umk.ac.id/files/prosiding/2019/6 Cintya Nurika_Irma.pdf

Damono, S.D. (1979). Sosiologi sebuah pengantar. Jakarta: Pusat Pembinaan dan Pengembangan Bahasa Departemen Pendidikan dan Kebudayaan.

Desri, A.E. (2019). Tafakkur dalam perspektif Al-Quran. Jurnal El-Qanuny. Diambil dari http://jurnal.iaim-padangsidimpuan.ac.id/index.php/elqanuniy/article/view/2154/172

Endraswara, S. (2003). Metodologi penelitian sastra epistemologi, model, teori, dan aplikasi. Yogyakarta: Pustaka Widyatama. . (2011). Metodologi penelitian sastra. Yogyakarta: CAPS. . (2016). Metode penelitian ekologi sastra konsep, langkah, dan penerapan. Yogyakarta: CAPS.

Lilik, N. (2016). Analisis tindakan sosial para tokoh dalam naskah drama Godlob karya Danarto dengan pendekatan sosiologi sastra Max Weber. Skripsi. Diambil dari http://eprints.unram.ac.id/9791/

Nurgiyantoro, B. (2013). Teori pengkajian fiksi.Yogyakarta: Gadjah Mada University Press. Pasaribu, R. (2017). Aku masenja.Yogyakarta: Araska.

Rafiek, M. (2013). Pengkajian Sastra: Kajian Praktis. Bandung: Refika Aditama.

Ritzer, G., \& Goodman, D. J. (2008). Teori sosiologi (edisi terbaru). Yogyakarta: Kreasi Wacana.

Siswantoro. (2005). Metode penelitian sastra: analisis psikologis. Yogyakarta: Pustaka Pelajar.

. (2016). Metode penelitian sastra analisis struktur puisi. Yogyakarta: Pustaka Pelajar.

Sugihastuti. (2007). Teori apresiasi sastra.Yogyakarta: Pustaka Pelajar.

Sugihastuti \& Suharto. (2002). Kritik sastra feminis, teori, dan aplikasinya. Bandung: Nuansa.

Susan. N.T., Zulfahita., \& Revi, J. (2019). Tindakan sosial tokoh utama dalam novel kerumunan terakhir karya Okky Madasari. Jurnal Cakrawala Linguista. Diambil dari https://journal.stkipsingkawang.ac.id/index.php/Cling/article/view/876/pdf

Susanto, H., \& Santoso, B.W.J. (2017). Wujud peralihan kode dalam peristiwa tutur informal masyarakat multietnis di stkip singkawang kalimantan barat. Jurnal Pendidikan Bahasa dan Sastra Indonesia Volume 2, Nomor 1, Page 26-30. Diambil dari https://journal.stkipsingkawang.ac.id/index.php/JP-BSI/article/view/235/192

Teguh, A.N., Herman, J.W., \& Suyitno. (2017). Kajian sosiologi sastra dan pendidikan karakter dalam novel simple miracles karya ayu utami serta relevansinya pada pembelajaran sastra di sma. Jurnal Ilmiah Didaktika Vol 18, No.1. Diambil dari http://jurnal.ar-raniry.ac.id/index.php/didaktika/article/view/3090/2203

Teuuw, A. (1967). Sastra Indonesia modern II. Jakarta: Pustaka Jaya. 


\section{MIMESIS}

Universitas

VOL. 2. No. 2, Juli 2021

Titje, P. L. (2019). Keberadaan bahasa rejang pesisir kabupaten bengkulu utara ditinjau dari segi kesantunan bahasanya. Jurnal Lateralisasi Volume 7 Nomor 2. Diambil dari http://jurnal.umb.ac.id/index.php/lateralisasi/article/view/551/416 